\title{
GENETIC VARIATION IN DNA OF COHO SALMON FROM THE LOWER COLUMBIA RIVER FINAL REPORT
}

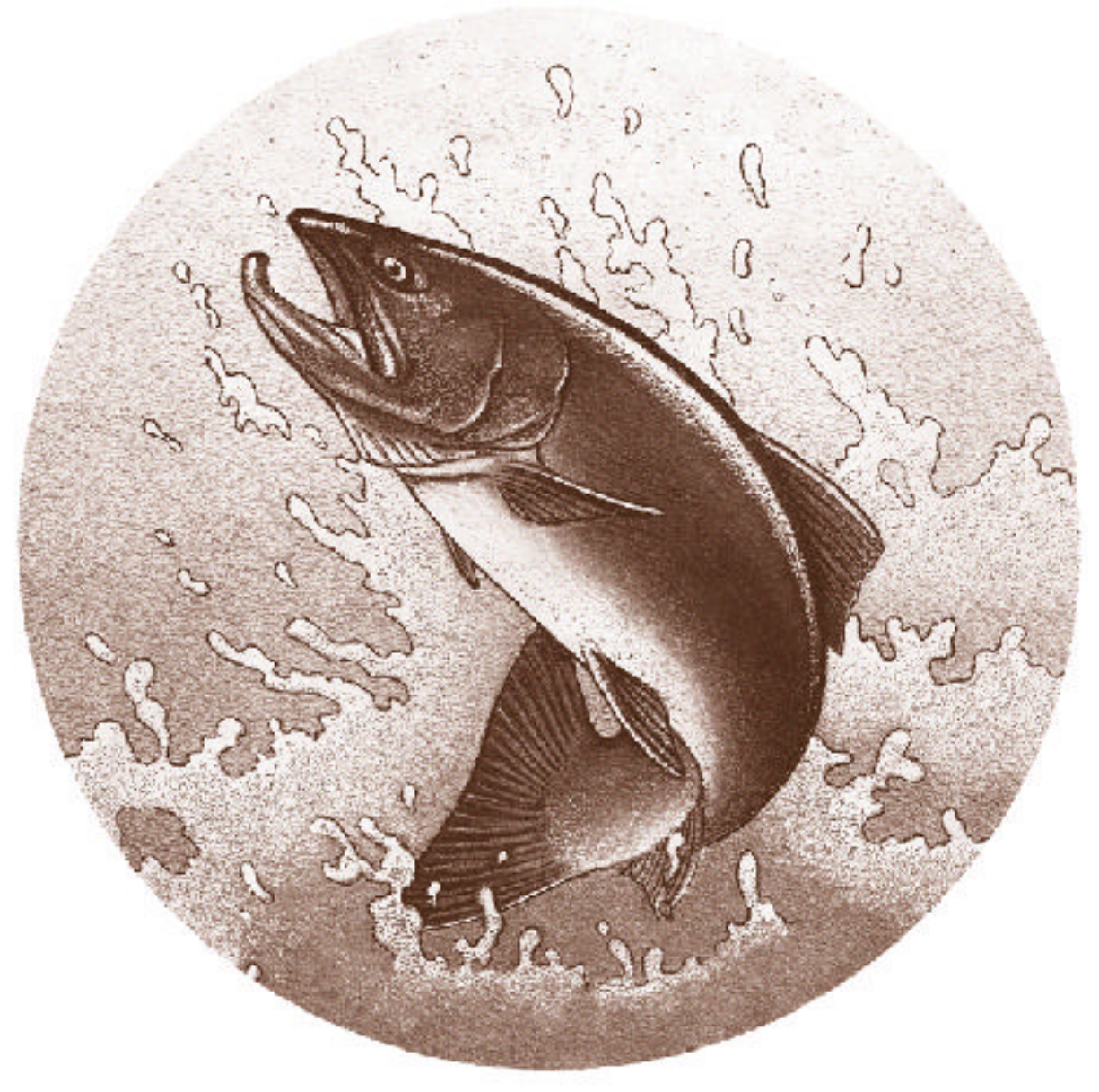

DOE/BP-30198-1 
DOE/BP-30198-1

This report was funded by the Bonneville Power Administration (BPA), U.S. Department of Energy, as part of BPA's program to protect, mitigate, and enhance fish and wildlife affected by the development and operation of hydroelectric facilities on the Columbia River and its tributaries. The views of this report are the author's and do $r$ necessarily represent the views of BPA.

This document should be cited as follows:

Fobes, Stephen; Kathy Knudsen, Fred Allendorf Division of Biological Sciences University of Montana, U. S

Department of Energy, Bonneville Power Administration, Division of Fish and Wildlife, Project Number 92-03,

Contract Number DE-BI79-92BP30 198, 29 electronic pages (BPA Report DOE/BP-30198-1)

This report and other BPA Fish and Wildlife Publications are available on the Internet at:

\section{http://www.efw.bpa.gov/cgi-bin/efw/FW/publications.cgi}

For other information on electronic documents or other printed media, contact or write to:

Bonneville Power Administration

Environment, Fish and Wildlife Division

P.O. Box 3621

905 N.E. 11th Avenue

Portland, OR 97208-3621 


\title{
GENETIC VARIATION IN DNA OF COHO SALMON FROM THE LOWER COLUMBIA RIVER
}

\author{
FINAL REPORT
}

\author{
Prepared by: \\ Stephen Fobes \\ Kathy Knudsen \\ Fred Allendorf \\ Division of Biological Sciences \\ University of Montana \\ Missoula, MT 59812
}

Prepared for:

U. S Department of Energy

Bonneville Power Administration

Division of Fish and Wildlife

P.O. Box 3621

Portland, OR 97283-362 1

Project Number 92-03 5

Contract Number DE-BI79-92BP30 198

APRIL 1993 


\section{ACKNOULEDGEMENTS}

Thi s research was funded by the Bonneville Power Admi ni strati on (Proj ect No. 92-035), Debbi e Watki ns, Proj ect Manager. We thank Kathryn Kost ow Oregon Department of Fi sh and Villd i fe (CDFW, Orl ay J ohnson, Nati onal Mri ne Fi sheri es Servi ce, and Ken Currens, Oregon Cooperati ve Fi shery Research Unit for provi ding sampl es of coho sal non, Ti m Schanber ( ODFW for the coho sal non used in experi mental matings, and Joan Strange and Tom North of the Uni versity of Mont ana Mblecul ar Bi ol ogy Facili ty for autonated DNA sequenci ng services.

\section{ABSTRACT}

The goal of this project was to devel op techni ques to provi de the i nf or mati on needed to determi ne if Lower Col unbi a Ri ver coho sal mon represent a "speci es" under the Endangered Speci es Act. Our report feat ures two new nucl ear DNA approaches to the i mproved detecti on of genet $i c$ vari ati on: 1) Studies of DNA I evel genetic variati on for two nucl ear grouth hor none genes; 2) Use of arbitrary DNA pri mers (randonly ampl i fied pol ynorphic DNA or "RAPD" pri mers) to detect vari ati on at I arge numbers of nucl ear genes.

We used the pol ynerase chai $n$ reacti on (PCR) to ampl i fy vari able secti ons (i ntrons) of two grouth hor mone genes ( $\mathrm{GH}$ I and $\mathrm{GH}-2$ ) in several sal nonid speci es. Coho sal mon had three DNA l ength vari ants for GH-1 intron C. Restriction anal ysi s and sequencing provi ded val uable inf or mati on about the node of evol uti on of these DNA sequences. We tested segregati on of the vari ants in captive broods of coho sal non, and denonstrated that they are al l el es at a single Mendel $i$ an I ocus.

Popul ati on studi es using the GH 1 al l el es showed hi ghl y si gnificant frequency differences between Lower Col unbi a Ri ver and Oregon Coast coho sal non, and nargi nal differences anong st ocks wi thi $n$ these regi ons. These new markers are adequatel y defi ned and tested to use in coho sal non popul ation studi es of any si ze. The nat ure of the vari ati on at GH-1 (Vari abl e Nunber Tandem Repeats, or "WNTR") suggests that more genetic vari ants will be found in coho sal non from other areas.

GH 2 intron C al so showed l ength vari ati on in coho sal mon, and thi s vari ati on was found to be sex-linked. Because PCR methods requi re minute anounts of ti ssue, this di scovery provides a techni que to determine the gender of i mat ure coho sal non wi thout killing them Chi nook sal non had restriction patterns and sequence di vergences si milar to coho sal mon. Thus, we expect that sex I i nkage of $\mathbf{G H} 2$ al l el es predates the evol uti onary di vergence of Pacific sal non species, and that gender testing wi th this system will work on the enti re group. Rai nbow trout do not show this sex-li nked variation.

Genetic markers detected by DNA ampl ification using arbi trary 10basepai $r$ pri mers (Randonl y Ampl i fi ed Pol ymorphi c DNA or "RAPD" narkers), are the newest and nost promising nethod of assessing vari ation at I arge numbers of genetic loci. We have denonstrated the inheritance of these markers in rai nbow trout, and we have found mul ti ple variable genetic markers in coho sal mon. Feasi bility studies on the use of RAPDs on I arge sal non coll ections are described. 


\section{NTRODUCTI ON}

El ectrophor etic anal ysi s of sol ubl e enzynes and restricti on enzyne anal ysi s of mitochondrial DNA have becone the mai nstays of appl $i$ ed popul ation genetics. As useful as these techni ques are, they detect onl y a portion of the genetic variation that DNA sequencing shows to be present for nost genes i n nat ural popul ati ons. However, the appl i cati on of newer DNA technol ogi es to popul ati on genetic anal ysi s, particul arly for nucl ear genes, has progressed sl ow y (Lewonti n, 1992). Neverthel ess, the prospect of i ncreased al l el i c resol uti on and the opportunity to study classes of genes other than sol uble enzymes are worthy reasons to pursue nucl ear DNA methods.

Because of the greater devel opment ef fort and hi gher costs i nvol ved, the pri mary focus must be on kinds of DNA variation that can be nost efficiently detected. The actual number of al I el es at the DNA I evel at any I ocus is rarel y known, but it is expected to be greater than the number of el ectrophoretic al I el es (Ranshaw et al., 1978). I n a st udy desi gned to detect the ful I extent of vari ation at one I ocus, Krei tman (1983) found 43 DNA pol ynorphi sns i n a 2721-bp regi on of the ADH I ocus in Drosophi la nel anogaster, whil e al l ozyme anal ysi s detected onl y the standard t wo (fast and sl ow) al lel es. Thi s work showed substanti al vari ati on in non-coding i ntrons and fl anking regi ons of the ADH I ocus.

Sequencing of miliple al leles is a feasi ble way to detect al lel ic variants, but a nore effici ent method than sequenci ng must be found to survey popul ati ons for this vari ation. Si ngl e nucl eoti de substit uti ons in PCRampl ified DNA can be detected by denat uring gradi ent gel el ectrophoresi s (Lessa, 1992), si ngl e strand conf or mati onal pol ynor phi sns (SSCPs, Ori ta et al., 1989), or restri cti on enzyne di gesti on (Karl and Avi se, 1992). Each of these techni ques, however, detects onl y a portion of the base substitutions that differ among al lel es; onl y sequencing can detect al I such differences.

Much geneti c vari ati on in i ntrons and ot her non-coding DNA is due to mutations that are I arger and easi er to detect than base substitutions. I nserti ons and del eti ons of mul ti pl e basepai rs result in length vari ants that are easily detected on el ectrophoretic gel s. Furthernore, many non-codi ng DNAs contai $\mathbf{n}$ tandenl y repeated sequences. Tandem repeats are prone to mitation by strand mispai ring mechani sns that are particular to such sequences ( Tautz et al., 1986; Tautz, 1989; Hardi ng et al., 1992). Thus, mul ti ple al l el es are often found that differ in number of repeat units (e.g., microsatel Iite sequences, mi ni-satellite sequences).

Length pol ynorphi sns are suffici ently comon in nost genones that they are an appropri ate focus for popul ati on geneti c anal ysi s (Tautz, 1989). However, most DNA based techni ques potenti al Iy detect vari ation at several rel ated l oci. Mul ti-l ocus systens are not sui table for many popul ati ongenet i c tests. Therefore, it is of ten necessary to show with inheritance data that DNA sequence vari ants segregate as al lel es at a si ngl e locus.

Demonstrating al l el i sm of DNA markers is particul arly i mportant i n sal moni $d$ fi shes because sal noni ds have many dupl i cated genes. The family Sal moni dae has a tetrapl oi d genone, due to a genome dupl i cati on event in the 
I i neage ancestral to the family. Di somic i nheritance has re-evol ved at many nucl ear I oci, but there remai $n$ tuo functi onal copi es of many genes (A I endorf and Thorgaard, 1984; J ohnson et al., 1987). PCR pri mers for known genes desi gned wi thout detai led know edge of di fferences bet ween dupl i cat ed I oci wi I I i kel y ampl ify sequences from both I oci. The two grouth hornone (GI) genes are the onl y dupl i cated pai $r$ of genes in sal moni ds for which both I oci have been sequenced (Agel I on et al., 1988b). Know edge of these sequences enabled us to desi gn locus-specific primers for ei ther GH gene.

Thi s paper describes PCR ampl ification of introns of the tuo grouth hor mone genes i n coho sal mon (Oncorhynchus ki sutch). We began a search for genetic pol ynorphism in coho sal mon with this approach because of the rel ative lack of i sozyme variation in this species and the need for finding genetic markers capable of di sti ngui shi ng between wi I nati ve and i ntroduced hatchery coho sal non in the Lower Col umbi a Ri ver. We desi gned PCR pri ners I ocated in coding DNA fl anking intron $C$. An intron is expected to have rel ati vel y high genet i c pol ymorphi sm because its non-codi ng DNA can tol erate base changes and length vari ation wi thout effects on fitness. We sel ected intron $C$ because its si ze ( 540 bp i n rai nbow trout GH 2; Agel l on et al., 1988a) is conveni ent for di rect sequencing of both strands. Here we report on a seri es of I ength variant al lel es at grouth hornone $1(\mathrm{GHI})$ and grouth hornone $2(\mathrm{G}+2)$ i ntron $C$ i n coho sal mon. We al so descri be a feasi bl y study of RAPD (Randont y Ampl i fi ed Pol ymor phi c DNA) geneti c narkers ( $V^{*} I$ I i ans et a l., 1990) i n sal moni d fi shes.

\section{MATER ALS AND METHODS}

Pooul ati on Samples The foll owing col l ecti ons of coho sal mon were provi ded by the Oregon Department of Fi sh and Vil dl i fe, Portl and: Sandy Hatchery, I ower Col umbi a Ri ver, Oregon ( $N=33$, St ock 11 , smol ts, 5/11/92); Rock Creek Hatchery, Umpqua Ri ver, Oregon $(N=30$, Stock 55, smol ts, 4/28/92); Nehal em $R i$ ver wi I 1 , north coast Oregon ( $N=28$, presnol ts, 6/24/92).

Addi ti onal coho sal mon uere provi ded by the National Mari ne Fi sheries Servi ce, Seattl e: $\quad$ khal em Ri ver wi Id 2, north coast Oregon ( $N=33$, fry, 5/14/92); Q ackanas Ri ver wi Id 1, I ower Col unbi a Ri ver ( $N=35$, NMFS \#30747, fry, 5/ 15/92); Cl ackamas Ri ver (North Fork Dan) wi I d 2 ( $N=19 / 20$, NMFS \#30746, numbered snolt tails, 5/15/92). Experi nental broods of the Arlee strai $n$ of rai nbow trout ( 0 . myki ss) and the Anaconda broodstock of westsl ope cutthroat trout (0. clarki lewisi) are mi ntai ned by our I aboratory. The Arl ee strai n of rai nbow trout is founded from multi ple wild stocks. It has hi gh di versi ty for al l ozymes rel ati ve to nat ural popul ations (Leary et al., 1983) and two very di sti nct nt DNA hapl ot ypes ( $S$. Forbes, unpubl i shed data). The Anaconda broodst ock of Westsl ope cutthroat trout is al so deri ved from mul ti ple sources. Three addi ti onal fry in the $\mathrm{Cl}$ ackamas $V^{*} / \mathrm{d} \mathbf{1}$ collection were $\mathrm{i}$ denti $\mathrm{i}$ ed as chi nook sal mon by di agnosti c al l ozyme al l el es at $C K-A 1, C K-A 2$ and PEP-A ( $R$. Leary, data not shown). I n Nbvember 1992 we obtai ned coho sal non ganet es from the Fal I Creek Hatchery (A sea Ri ver, mid-coast Oregon) to make experi mental crosses. Ti ssues from the parents were kept for genetic analysis. 
Methods DNA i sol ati ons were perforned on $50-100 \mathrm{mg}$ muscl e or I i ver ti ssue by the phenol/ chl or of orm extracti on method of W' rgi $\mathbf{n}$ et al. (1990). PCR pri mer sequences for grouth hornone intron C uere I ocated at positions in GH-1 and GH-2 exons 2 and 3 that are conserved anong publ i shed rai nbow trout, coho sal mon, and chum sal mon sequences (Agel I on et al., 1988b; Gonzal ezVi I asenor et al., 1988; Seki ne et al., 1985,1989). A si ngl e nucl eoti de si te differs bet ween the I oci at the 3-pri ne end of each primer. These primers are perfect matches to the publ $i$ shed sequences of rai nbow trout $G H-1$ and $G H-2$ and coho sal mon $\mathbf{G H} 1$.

Lef $t \quad$ Ri ght

$\mathrm{GH}-1$

$\mathrm{GH}-2$

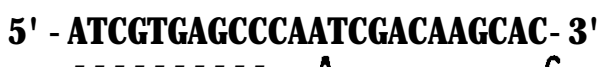

5 ' - GGGTACTCCCAGGATTCAATCAGA-3'

I nt ernal pri mers were al so used on the I onger GH-1 i nt rons in coho sal non: l eft 5' - GCAAGCAGACCACCAATTATG 3' ; ri ght 5' - AAACCACCGATTAGACAGTGATG- 3' .

PCR reacti ons contai ned $100 \mathrm{mM}$ Tri s- $\mathrm{HCl}$ pH 8. 3, $500 \mathrm{mM} \mathrm{Ka} \mathrm{,} \mathrm{4.} 0 \mathrm{mM} \mathrm{MgCl}{ }_{2}$, $2 \mathrm{ug} / \mathrm{ml}$ BSA, 0.2mM each dNTP, 0.5uM each pri mer, 0.5U Taq DNA pol ymerase (Perki n- El ner Cetus or Pronega Corp.), and 50-100ng templ ate DNA i n a tot al vol une of 25ul. Thi rty cycles of $92^{\circ} \mathrm{C} 1 \mathrm{~min}$, $62^{\circ} \mathrm{C} 1 \mathrm{~min}$, and $72^{\circ} \mathrm{C} 1 \mathrm{~min}$. were foll owed by $3 \mathrm{~min}$. at $72^{\circ} \mathrm{C}$. The i nternal pri mers for GH-1 used the sane thermal program except with $56^{\circ} \mathrm{C}$ anneal ing for $1 \mathrm{~min}$. Tho to ten ul of each PCR reacti on were run on $2.5 \%$ agarose gel s in TAE buffer contai ni ng et hi di um bromide. One ug $1 \mathrm{~Kb}$ DNA I adder ( $\mathrm{G}$ bco-BRL) was used as a si ze standard.

Restriction di gests of PCR products contai ned 2-10 ul of each reaction and 5 uni ts of enzyme in a total vol ume of $20 \mathrm{ul}$, adj usted to the manuf act urers' (Boehri nger Mannhei mBi ochemi cal s) recommended condi ti ons. Restriction products uere run on agarose gel s as above, or on $6 \%$ or $12 \%$ pol yacryl ani de gel s i $\mathbf{n}$ TBE, and st ai ned wi th et hi di um broni de. GH-1 and GH-2 PCR products were screened with 34 restriction endonucl eases: AluI, Apa I, AvaI, AvaII, AsnI, BamHI, BclI, BglI, BglII, BstEII, CfoI, DdeI, DraI, EcoRI, EcoRV, HaeIII, HindII, HindIII, HinfI, HpaI, KpnI, MspI, Ncil, NdeII, NheI, PstI, PvulI, RsaI, ScaI, Scrfi, StuI, StyI, TaqI, XbaI.

DNA was prepared for sequenci ng by runni ng 20 ul PCR reacti on product i n a $2.5 \%$ agarose gel and exci si ng the desi red bands. Si ngl e al l el es for I ength vari ants were i sol at ed as bands of uni que si ze from het erozygous i ndi vi dual s. If necessary to produce enough templ ate, si ngl e al l el es were re-ampl ifi ed from a gel slice soaked in 100 ul TE and frozen overnight at $-40^{\circ} \mathrm{C}$. Templ ate DNAs were purified from gel sli ces usi ng GeneClean (Biolol, Inc.). Aut onated sequencing was done by dye termination PCR cycle sequenci ng, using the ori gi nal ampl i fi cati on pri mers, i n an Appl i ed Bi osystens I ncorporated 373A aut omated DNA sequencer. An internal sequencing pri ner uas used for sone templ ates: I ef t pri ner - 5' -CCCCGATTGTCTAAACTCC - 3 '. 
RESULTS

GH-1 and G+ 2 intron C PCR Products Tuo pri mer-specific si ze classes of GH i ntron C products corresponding to the GH-1 and $\mathrm{G}+2$ I oci were produced i $n$ ampl i f $i$ cati ons from each sal moni d speci es tested (Tabl e 1). GH-1 products were about 820 bp, except in coho sal mon, where they were several hundred bp l onger. G+2 products were about 540 bp in al I four species. Thi s cl osel y matched the si ze predi cted from a genomic cl one of rai nbow trout G+2 (Agel I on et al., 1988b). Products from both genes showed length vari ati on in coho sal mon: three si zes at GH-1 (Table 1; Fi g. 1) and two si zes at GH-2 (Table 1).

A I GH-1 and G+ 2 PCR products from al I four speci es were di gested wi th HinfI ( Table 1). Al si tes uere conserved anong speci es and anong al lel es except one di sti ngui shi ng the $\mathrm{G}+2$ products i $n$ coho sal mon. We al so di gested apparent homozygotes for each al l el e at GH-1 and $\mathbf{G + 2}$ i $\mathbf{n}$ coho sal mon wi th 33 ot her restriction enzymes (Table 2). Ei ght een enzynes cut one or nore al lel es. At $\mathrm{GH}-1$, there were no restriction si te differences anong I ength variants for any enzyme. In contrast, the two al leles at $\mathbf{G + 2}$ differed at si $x$ restriction si tes. Restriction di gesti on did not reveal nore vari ants at ei ther I ocus than were detectable by PCR product I ength anal ysi s al one.

Aut onated cycle sequencing provi ded accurate, reproduci bl e sequence data to at l east $300 \mathrm{bp}$ from ei ther pri mer. Opposite strand sequences usual Iy overl apped i $\mathbf{n}$ the middl e, except for coho GH-1 sequences, whi ch were too I ong to sequence ful Iy from the ends. Internal pri mers for coho GH-1 gave sequences that read through the central tandem repeat regi on. Fi gure 3 shows the I ongest al I el e $\left(G H-I^{\star} a\right)$, with a consensus sequence of the tandem repeat regi on in al I three al lel es. The number of repeats in each of the three al lel es expl ai ns the I ength di fferences seen on agarose gel s. The AGCC not if that punct uates the 31-bp, AT-rich repeats gave a strong si gnal throughout. However, because sequencing accuracy was poor in thi s regi on, probably because of its repeated structure, it is not certai $n$ that al $\mathrm{I}$ repeat units are i dentical. G+2 from rai nbow trout nearly matched the publ i shed sequence for a genomi c cl one of a GH gene (Agel I on et al., 1988b). Posi ti ons of al I restriction sites shown in Table 2 were later confirned by sequencing.

I nt erspeci es sequence di vergences of this GH-1 intron are hi gher than for GH-1 exons, and I ouer than for mitochondri al DNA Evol uti onary di vergences anong al l el es and anong speci es for GH-1 sequences were measured by al i gni ng al 1 fi ve sequences, di scount ing the gaps, and count ing the number of mi snatched bases (Table 3 ). Exon sequences (CDNAs) for this compari son were avai I abl e onl y for coho sal non (Gonzal es- Vi I I asenor et al ,, 1988) and rai nbow trout (Agel I on et al., 1988b). The mean di vergence of i nt ron C bet ween the three coho al I el es and rai nbow GH-1 i s 2.5 percent (Table 3). Thi s is nearly twi ce the val ue (1.4\%) for GH-1 exon sequences. In a 2214- bp segment of mitochondri al DNA the coho-rai nbow di vergence is 7.2 percent (Thomas and Beckenbach, 1989).

We tested segregati on of the coho sal mon I ength variants at $\mathrm{GH} 1$ i $\mathrm{n}$ experi mental crosses ( Table 4; Fig. 4). When the parents were al ternate homozygotes, al I 20 progeny were heterozygotes. When ei ther parent al one was heterozygous, the 20 progeny showed 1:I segregati on from that parent. The 
I ength vari ants produced by $G H-1$ i ntron C pri mers i n coho sal non are cl early al l el i c.

GH-1 genot ypes were recorded for 203 coho sal non i n seven wild and hatchery col l ecti ons ( Tabl e 5). A I sampl es conf orm to expected bi nomial ( Hardy- Wei nberg) genot ype proporti ons, suggesting that they are from random nating popul ations of reasonable size. We tested al l pairs of collections for gene frequency differences wi th $2 \times 3$ conti ngency tests (Table 6). The seven collections fal I clearly into a coastal Oregon group and a Lower Col unbi a Ri ver group, si nce nost pai rui se tests bet ween these cl usters fal I bel ow the $p=0, \infty$ si gni fi cance I evel (Tabl e 6, Fi g. 5). The onl y except i on is Rock Creek Hatchery (Umpqua Ri ver, Oregon), whi ch nore cl osel y resenbl es the I over Col umbi a stocks than the coastal stocks. Vild fi sh in each group do not differ si gnifi cantly from the hatchery in that group (Sandy Hatchery vs. Cl ackanas wi Id, Fal I Creek Hatchery vs. Nehal em wi I d).

Sex I i nkaqe of $\mathrm{G}+2$ We desi gnated the two coho $\mathrm{GH} 2$ al I el es $\mathrm{GH}-2^{\star} \mathrm{a}$ ( $530 \mathrm{bp}$ ) and $\mathrm{GH}-2^{\star} b(551 \mathrm{bp})$. The 21-bp di fference is detectable on hi gh concentrati on agarose gel s. However, we routi nel y i dentifi ed $G H-2 \star b$ by a di agnost i c 456- bp HinfI restri cti on fragment (Table 1; Fi g. 2; Fi g. 6). I n col l ecti ons of coho sal mon I arge enough to sex (>100mm), al I the mal es had a bri ght $G H-2{ }^{*} b$ band, whil e al I the fenml es had no $G H-2 \star b$. The associ ati on of $G H-2 \star b$ and phenotypi c male sex was perfect in a total of 27 female and 36 male coho sal mon ( Table 7). The frequency of the male-specific marker in collections of fry that were too snal l to sex was 0.52 i $n$ Nehal em Ri ver wi ld coho and 0.51 i n Cl ackanas Ri ver wi Id coho, consi stent wi th sex I i nkage i n these popul ations as wel I (Table 7). Progeny in three experi nental crosses had the paternal band in one-half the progeny (Table 8; Fi g. 2).

We al so studi ed restricti on patterns and sequences of $\mathbf{G +} 2$ markers i $n$ ot her sal monid speci es. G+2 restriction patterns from chi nook sal mon appear si milar to the coho sal mon patterns. That is, there are tuo types of i ndi vi dual s that correspond to the *aa femal e and *ab mal es seen in coho sal mon on the basi $s$ of the size of the products and the HinfI restriction patterns (Table 1). Rai nbow trout and westsl ope cutthroat trout (subgenus Parasal no) have I ess $\mathbf{G}+2$ vari ati on than the two sal non speci es. There was no l ength variation in $\mathbf{G + 2}$ products anong 71 rai nbow trout and 22 westsl ope cutthroat trout. There uas al so no $\mathbf{H}$ nf I restriction si te vari ation at $\mathbf{G H} 2$ i 69 rai nbow trout and 12 cutthroat trout.

DNA sequences of the $G+2$ al I el es from coho sal mon (Fig. 6) corroborated the striking degree of di vergence i ndi cated by restriction di gests. A I $G H-2^{\star}$ a sequences were put at i ve di pl oi ds because the al I el e is X-I i nked; GH-2*b sequences are of si ngl e al lel es. We compared pairs of sequences by al i gni ng the sequences, di scounting the gaps, and counting the DNA base mi smatches (percent sequence di vergence; Table 9). The sequence di vergence bet ueen the $G H-2^{\star} a$ and $G H-2^{\star} b$ al I el es is remarkable. In coho sal mon, $G H-2^{\star} a$ and $G H-2^{\star} b$ differ by 6.5 percent, and in chi nook sal non these allel es differ by 7.4 percent (Table 9). These i ntraspeci es differences are I arger than the di vergence of ei ther al I el i c type bet ween species ( 0.9 percent for $G H-2 \star a, 3.9$ percent for $G H-2 \star b ;$ Fi g. 7). 
Another di fference bet ween $G H-2^{\star} a$ and $G H-2^{\star} b$ was in the rel at i ve i ntensity of the amplified bands. GH-2*b was al ways bri ght when present, but $G H-2{ }^{\star} a$ vari ed from a bri ght ness equal to $G H-2{ }^{*} b$ to near i nvisi bi I ity. A fai nt band mat chi ng GH-2*a i n si ze appeared i $\mathbf{n} \mathbf{G H} 1$ ampl i fi cat i on from every coho i ndi vi dual ( Fi g. 1). Restri cti on enzymes whi ch cut $G H-2^{\star} a$ al so cut thi s band. Sequenci ng of the band conf i rmed it to be i denti cal to GH-2*a (data not shown). However, no $G H-2 \star b$ product was seen $i \mathrm{n}$ any $\mathrm{GH} 1$ ampl i fi cation. We i nfer from this that $G H-2{ }^{\star} a$ al lel es have a cryptic change in a PCR pri ming si tes that matches the $3^{\prime}$ end of a GH-1 pri ner. Thi s mitation results in weak ampl i fi cati on with GH-1 pri mers. A so, pri mer si te pol ynorphi sns apparent ly cause vari abl e ampl ifi cati on effi ci ency of $G H-2^{\star}$ a rel at i ve to $G H-2^{\star} b$ anong i ndi vi dual s. We took advant age of weak $\mathrm{GH}-2{ }^{\star} a$ ampl i fi cat i on i n sel ected i ndi vi dual s to obtai $n$ cl ean sequenci ng templ at es for $G H-2 \star b$.

Nucl ear DNA "RAPD" Markers We al so tested the RAPD (Random y Ampl i fi ed Pol ymorphi c DNA) techni que for measuring genetic differences anong popul ations. These genetic narkers detected by DNA ampl ification usi ng arbi trary 10-basepair pri mers are a new and promi si ng method of assessi ng vari ation at I arge numbers of genetic I oci ( $V^{4} I$ II ians et al., 1990). However, the techni que is so new that there are no published accounts of use of the nethod in salmonid fi shes, and none di scussing the use of such data for popul ation genetic purposes. We have denonstrated the inheritance of 14 of these markers in the Arl ee strai $n$ of rai nbow trout (data not shown). We have al so found 14 vari able genetic markers in coho sal mon DNAs usi ng 15 di fferent RAPD pri mers (Table 10). Si nce there are over 500 RAPD pri mers comerci al Iy avai I able, thi s method can potentially screen a vast number of genetic narkers in the coho sal mon nucl ear genone. A test for narker frequency differences bet ween Sandy and Rock Creek hatchery coho usi ng si $x$ vari abl e RAPD markers reveal ed a margi nal I y si gni fi cant $(P<0.1)$ di fference (Table 11). Thi s is concordant with the anal ysis of these collections with the GH-1 markers. Efforts to extend this anal ysis to nore primers and nore collections met with techni cal diffi cul ti es (see Di scussi on).

\section{SCUSSI ON}

Choi ce of $\mathrm{Mblecular}$ Genetic Techniques Appropri ate choi ce of a nol ecul ar techni que for studying popul ati on struct ure depends upon: (1) The f undamental ability of a techni que to reveal genetic variation, (2) The nat ure of the variation actual ly present in the study popul ations, (3) The costeffectiveness of the techni que for surveying I arge numbers of I oci in nany i ndi vi dual s, and (4) The facility with which a general strategy, once devel oped, can be appli ed to new l oci or to new study speci es.

A though al I ozyme anal ysi s can exami ne I arge numbers of I oci, it reveal s onl $y$ a portion of the total al I el ic variation at each I ocus, and it onl $y$ addresses a si ngl e cl ass of structural genes. Mtochondrial DNA restriction anal ysi s or sequenci ng of ten reveal s a larger number of vari ants. Fourteen hapl ot ypes were found in Whshi ngt on State coho popul ati ons ( $P$. Mran, personal communi cation), and seven hapl otypes were found in pil ot st udi es of Louer Col unbi a Ri ver coho sal mon ( $K$ Currens, personal commini cation). However, 
mtDNA is effecti vel y onl y one I ocus, and its hapl oi d, maternal mode of i nheritance makes it not necessarily representative of the nucl ear genome.

A l ozynes are still frequently the method of choice for many fi sheries appl i cati ons (Utter 1991). However, some speci es have too I ittle al lozyme vari ati on to be usef ul. Lower Col unbi a Ri ver coho sal non fall in this category. Vari ant al lozyme al l el es in coho are generally rare (Wehrhahn and Powel I, 1987; Rei senbi chl er and Phel ps, 1987; J ohnson et al ., 1991) gi vi ng Iittle statistical power to study popul ation differences.

PCR Amplification of Nucl ear I ntrons We have found that genetic vari ation that is detectable as PCR product I ength differences can be efficiently surveyed in natural populations. This result is far more i mportant than the fact that grouth hormone genes in particular are usef ul for thi s purpose. Whet her I ength vari at i on is common i $n$ ot her sal moni d genes is not yet known. We expect that such vari ati on is qui te gene- and speci esspecific, si nce coho sal non showed I ength vari ants in this st udy, and rai nbow trout and cutthroat trout di d not. Neverthel ess, many non-codi ng DNAs in al I speci es di spl ay I ength vari ation, and this study shows that I ength vari ants can be efficiently scored, once detected. We esti mate the cost of using a devel oped si ngl e-l ocus system such as GH-1, at about $\$ 1.50$ per fi sh. Si nce much of thi s cost is for preparation of sample DNAs, the cost woul d be l ess for addi ti onal I oci. Thi s cost does not i ncl ude I abor, devel opnent or equi pment costs.

The pol ynerase chai $\mathbf{n}$ reacti on is a boon to popul ati on geneti ci sts. It permits genetic studi es to be done usi ng muscul e, non-l ethal sampl es, and it has been found very effective for mitochondrial DNA studies in fi shes (Beckenbach, 1991; Whitmore et al. , 1992). It al so potent i al I y targets genet i c vari ati on that is not accessi bl e to ot her nethods. However, as the present study shows, devel opnent of a system to detect vari ation in known di pl oi d nucl ear genes, especi al I y i n a speci es wi th many dupl icated genes, is not si mple. Because l ocus-specific pri mers must be devi sed and the i nheritance of markers tested, the promise of this approach for salmonid popul ation genetics will i mprove onl y as fast as the database of single copy gene sequences in salmonid fi shes grous.

Population Structure of Coho Sal mon GH-1 al I el e frequenci es show a stri ki ng di fference bet ween Oregon coast and Lower Col unbi a Ri ver (LCR) coho sal mon st ocks. Genetic di sti ncti veness is one of several fact ors i nvol ved in i dent i fyi ng Evol uti onari l y Si gni fi cant Uni ts (ESUs) under the Endangered Speci es Act (Whpl es, 1991). Our resul ts provi de evi dence that Col umbi a Ri ver and coastal coho sal mon bel ong i n separate ESUs.

Another i mportant comparison is that of putati ve wild coho sal mon and I ocal hatchery st ocks. Evi dence of a geneti cal I y uni que wi I d-spauni ng coho sal mon run in the Lower Col umbia Ri ver would warrant its Iisting as an ESU (Oregon Trout and Paci fi c Power, 1991; Wttki ns and Vi gg, 1991). We found no difference in GH-1 al l el e frequenci es between two sampl es of put at i ve wi I d fi sh from the $\mathrm{Cl}$ ackanas Ri ver and one col I ecti on from Sandy Hat chery, whi ch has had hi storical contri buti ons from the $\mathrm{Clackanas}$ as well as from other I ower Col unbi a hatcheries. Nei ther were the Fall Creek hatchery coho sal non 
si gni fi cantl y di fferent from wi I Nehal em Ri ver coho sal non. We must emphasi ze, however, that al though a gene frequency difference can denonstrate that two popul ations do not randonly i nterbreed, a I ack of differentiation at one l ocus does not prove tuo stocks are not different. Stock structure anal ysis with GH-1 markers can be enhanced in the fut ure by testing I arger collections of fish, but it will be even better enhanced by looking at more di ff erent genes ( $\mathrm{Nei}, \mathrm{1987}$ ).

G+2 al I el es are sex-I i nked The $G H-2{ }^{*} b$ al I el e detected by HinfI di gesti on of G+2 specific PCR products is unequi vocally Y-chronosone I i nked in coho sal mon. We expect that sex I inkage of $G+2$ al l el es predates the evol uti onary di vergence of Pacific sal mon species, because of the apparent honol ogi es bet ween coho and chi nook sal mon for $G H-2{ }^{\star} a-$ and $G H-2 \star b-t$ ype al I el es.

Because PCR methods requi re mi nute anounts of tissue, this di scovery provi des a techni que to determi ne the gender of i mat ure sal mon from a smal I fin clip without killing the fish. Such a procedure was devel oped using a di ff erent Y-I i nked DNA marker i $n$ chi nook sal mon (Devl i n et al., 1991), but it works onl y on chi nook sal mon. Because the $\mathbf{G + 2}$ al I el es are conserved i n coho and chi nook sal mon, we expect that they will work for sex identification in other Pacific sal mon species not yet tested. Rai nbow trout and cutthroat trout, however, do not show sex-specific l ength variation in thi s $\mathbf{G + 2}$ intron. Fut ure comparative studi es of this regi on of the genone in trout and sal non will be hi ghl $y$ inf ornati ve about the evol uti on of sex determation.

RAPD Markers The use of RAPDs for popul at i on genetics is unproved. The strength of the RAPD techni que I i es in the opport unity to assess a I arge number of markers withi $n$ a si ngl e controlled experi ment. The mai $n$ weakness is a technical sensitivity that nakes it difficult to replicate results. The coho results described above are a best-case example of controlled conditions. Al the DNAs were i sol ated by the same procedure, and reactions were run consecuti vel y on a si ngl e PCR machi ne under i denti cal conditions. The results appear reliable. However, nechani cal difficulties with PCR machi nes have prevented us from repl i cating these results, or extendi ng the study. Anot her I ab could use the sane primers with the sane fish, and I ikely would get a si milar measure of genetic di stance, but thei $r$ data and ours noul $d$ not be comensurable on a marker-for-marker basi s.

We do not feel that the RAPD techni que as it exi sts is robust enough to serve wi del y i n salmonid st ock i dent $i$ fi cati on, where compari son of data anong di fferent coll ecti ons from different I abs is necessary. At present, even wi thi $n$ one $I a b$, the need for repl i cate controls to assure comparability anong data sets seri ousl y compromises the theoretical advantages of the techni que. However, RAPDS have greater promise for focal studi es of pai rs of popul ati ons of particul ar interest, where broader compari sons are not necessary. This prospect warrants research on techni cal i mprovenents to make the RAPD techni que more consi stent. For genetic mapping studi es, where tests wi thi n si ngl e experi nents are hi ghl y i nf ormati ve, RAPDs are al ready promising. Our i ni ti al studi es showed good Mendel $i$ an i nheritance of RAPD markers wi thi $n$ families of rai nbow trout. Wh have al so begun a study to gene-centromere nap vari abl e RAPD bands wi thi $n$ gynogenetic di pl oi d broods of rai nbow trout. 


\section{TERATURE CI TED}

Agel I on, L. B. , S. L Davi es, T. T. Chen, and D. A Powers. 1988a. Structure of a fi sh ( rai nbow trout) grouth hornone gene and its evol uti onary i mpl i cati ons. Proc. Natl. Acad. Sci . U. S. A 85:5136-5140.

Agel I on, L. B. , S. L Davi es, C. - M Li n, T. T. Chen, and D. A Powers. 1988b. Rai nbow trout has two genes for grouth hornone. Mbl. Reprod. Dev. I : I I - 17.

A I endorf, F. W and G. H Thorgaard. 1984. Tet rapl oiidy and the evol uti on of sal moni d fi shes, pp. I-53. In B. Turner (ed.), Evol uti onary Geneti cs of Fi shes. Pl enum Press, New York.

Beckenbach, A T. 1991. Rapi d nt DNA sequence anal ysi s of $\mathbf{f}$ i sh popul ati ons usi ng the pol ynerase chai $n$ reacti on (PCR). Canad. J. Fi sh. Aquat. Sci . 48: 95- 98.

Devl i n, R. H, B. K. MeNei I, T. D. D. Groves, and E. M Donal dson. 1991. I sol ati on of a Y-Chronosonal DNA probe capable of determining genetic sex i n chi nook sal mon (Oncorhynchus tshauytscha). Can. J. Fi sh. Aquat. Sci . 48: 1606- 1612.

Gonzal ez-Vi I I asenor, L.I., Zhang, P. , Chen, T. T. and D. A Powers. 1988. Mbl ecul ar cl oni ng and sequenci ng of coho sal mon grouth hor mone. Gene 65: 239- 246.

Hardi nq, R. M, A. J. Boyce, and J. B. Q eqq. 1992. The evol ut $i$ on of tandent $y$ repeti ti ve DNA: recombi nati on rul es. Geneti cs 132:847-859.

J ohnson, K. R. ; Wi ght J r. , J . E. ; Myy, B. 1987. Li nkage rel at i onshi ps ref I ecti ing ancestral tet rapl oi dy in sal moni d fi sh. Genet i cs $116: 579-591$.

Johnson, Q. W, T. A FI agg, D. J. Maynard, and F. W Whknitz. 1991. Status Revi ew for I ower Col unbi a Ri ver Coho Sal non. U. S. Dep. Commerce, NOAA Techni cal Menorandum 96 pp.

Karl, S. A, and J.C. Avi se. 1992. Bal anci ng sel ecti on at al l ozyne loci in oysters - I mpl i cati ons from nucl ear RFLPS. Sci ence 256:100-102.

Krei t man, M 1983. Nucl eoti de pol ynorphi sm at the al cohol dehydrogenase I ocus of Drosophi Ia melanogaster. Nature 304:412-417.

Leary, R. F., F. W A I endorf and K. L. Knudsen. 1983. Devel opmental stabi I i ty and enzyme het erozygosi ty i n rai nbow trout. Nat ure 301:71-72.

Lessa, E. P. 1992. Rapi d surveyi ng of DNA sequence vari ati on i n nat ural popul ati ons. Mbl. Bi ol. Evol. 9:323-330.

Lewont i n, R. C. 1992. El ectrophoresi s in the devel opment of evol uti onary geneti cs: milest one or mill st one? Geneti cs 128:657-662. 
Nei, M 1987. Mbl ecul ar Evol uti onary Geneti cs. Col unbi a Uni versi ty Press, New York.

Oregon Trout and Paci fic Power. 1991. Request to the Nati onal Mari ne Fi sheri es Servi ce to reconsi der its deci si on on the wild Lower Col umbi a Ri ver coho under the Endangered Speci es Act. Oregon trout, Portl and, Oregon. Paci fic Power, Portl and, Oregon. 21 pp.

Orita, M, I. H royuki, H Kanazana, K. Hayashi, and T. Seki ya. 1989. Detecti on of pol ynorphi sns of human DNA by gel el ectrophoresi s as si ngle strand conf or mati on pol ynorphi sns. Proc. Nat. Acad. Sci . USA 86: 27662770.

Ranshaw J.A.M, J.A Coyne, and R. C. Lewonti n. 1979. The sensiti vi ty of gel el ectrophoresi s as a detect or of genetic vari ation. Geneti cs 93:10191037.

Rei senbi chl er, R. R. and S. R. Phel ps. 1987. Genet i c vari ati on i n chi nook, Oncorhynchus tshawytscha, and coho, 0 . ki sutch, sal non from the north coast of Whshi ngt on. Fi sh. Bul I . 85: 681-701.

Seki ne, S., T. M zukami, T. N shi, Y. Kuwana, A Sai to, M Sat o, S. Itoh, and H Kawauchi . 1985. Cl oni ng and expressi on of cDNA for sal non grouth hor mone i n Escheri chi a col i. Proc. Natl. Acad. Sci . U. S. A 82: 4306- 4310.

Seki ne, S., T. Mzukam, A Sai to, H Kauauchi, and S. It oh. 1989. I sol ati on and characterizati on of a novel grouth hornone cDNA from chum sal non (Oncorhynchus keta). Bi ochi m Bi ophys. Acta 1009:117-120.

Tautz, D., M Trick, and G. A Dover. 1986. Cryptic si mplicity in DNA is a naj or source of geneti $c$ vari ati on. Nat ure 322: 652-656.

Tautz, D. 1989. Hypervariability of si mple sequences as a general source for pol ynor phi c DNA narkers. Nuc. Aci ds Res. 17: 6463-6471.

Thomas, WK, and A. T. Beckenbach. 1989. Vari ati on i n sal moni d mi tochondri al DNA: Evol uti onary constrai nts and mechani sns of substi tuti on. J. Mol . Evol. 29: 233- 245.

Utter, F. M 1991. Bi ochemical geneti cs and fi shery managenent - An hi st ori cal perspecti ve. J.Fi sh Bi ol . 39:1-20.

Whpl es, R. S. 1991. Defi ni ti on of "Speci es" Under the Endangered Speci es Act: Appl i cat i on to Paci fi c Sal mon. U. S. Dep. Commerce, NOAA Techni cal Menorandum NMFS F/ ML- 194, 29 pp.

Wht ki ns, D. and S. Vigg. 1991. Comments of the Bonneville Power Admi ni strati on on the Nati onal Mari ne Fi sheries Servi ce determination to not propose Iisting of the Lower Col umbi a Ri ver coho sal mon under the Endangered Speci es Act. Portl and, Oregon. 40 pp. 
Whhrhahn, C. F., and R. Powel I. 1987. El ectrophoreti c vari ati on, regi onal differences, and gene fl ow in the coho sal non (Oncorhynchus ki sutch) of sout hern British Col umbi a. Can. J. Fi sh. Aquat. Sci . 44: 822-831.

Whi tmore, D.H., T. H Thai, and C.M Craft. 1992. Gene amplification permits mi nal l y i nvasi ve anal ysi s of fi sh mitochondrial DNA Transactions of the Ameri can Fi sheri es Soci ety 121: 170-177.

Vill i ans, J.G K, A R. Kubel i k, K. J. Li vak, J.A. Raf al ski, and S. V. Ti ngey. 1990. DNA pol ynorphi sns ampl ified by arbi trary pri ners are usef ul as genet i c markers. Nucl. Aci ds. Res. 18: 6531- 6535.

V̈̈rgi n, I.I., M D Anore, C. Grunual d, A Gol dnan, and S.J. Garte. 1990. Genetic di versity at an oncogene I ocus and in mitochondri al DNA bet ween popul at $i$ ons of cancer-prone At I ant i c toncod. Bi ochem cal Genet i cs 28: 459- 476. 
Table 1. Fragnent si zes of i ntron C PCR products from grouth hornone 1 and grouth hor mone 2 i n coho sal mon, chi nook sal non and rai nbow trout. Al restriction si tes were confirned by sequencing. Fragments I ess than 50 bp uere detected by sequencing onl $\mathbf{y}$. $\mathbf{N}=$ number of al l el es tested, assuming di pl oi dy at both I oci .

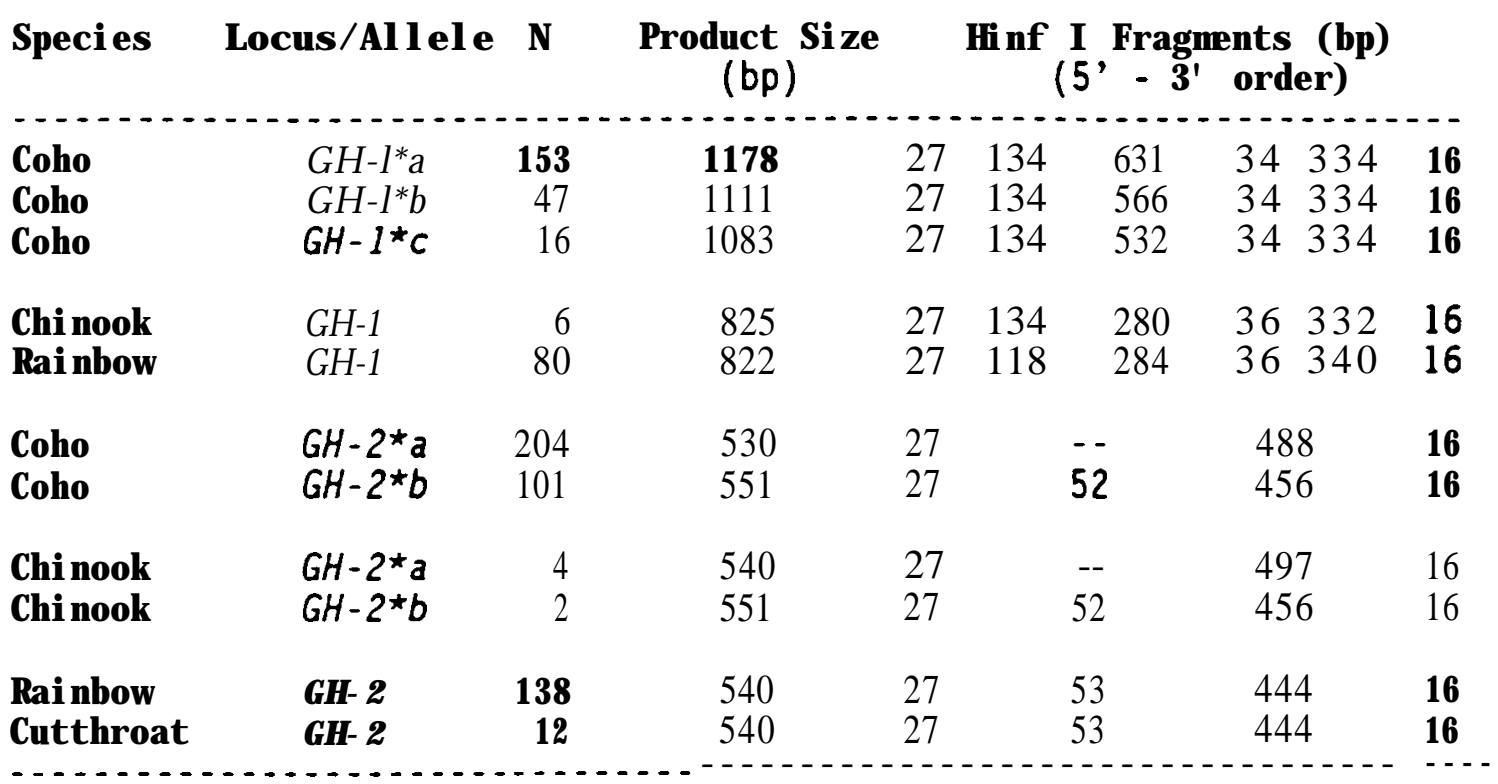


Table 2. Restri cti on anal ysi s of $G H-1$ and $\mathrm{G}+2$ i ntron C PCR products from coho sal mon. $\mathbf{0}=$ enzyme does not cut al l el e. $\mathbf{N}=$ number of al l el es test ed. For GH-1 onl y the *a al I el e (1176 bp) is shown; the *b and *c al l el es have the sane restriction si tes, and differ from ${ }^{*}$ onl $y$ i $n$ I ength.

\begin{tabular}{|c|c|c|c|c|c|c|}
\hline \multirow[b]{2}{*}{ Enzyne } & \multicolumn{2}{|l|}{$\mathrm{GH}-\mathrm{I}^{*} \mathrm{a}$} & \multicolumn{2}{|c|}{$G H-2 * a$} & \multicolumn{2}{|l|}{$G H-2 \star b$} \\
\hline & bp & $(N)$ & bp & (N) & bp & (N) \\
\hline Uncut & 1176 & & 530 & & 551 & \\
\hline AluI & $815 / 244 / 73 / 45$ & (18) & $485 / 45$ & (4) & $506 / 45$ & (2) \\
\hline AsnI & 0 & (19) & 0 & $(26)$ & $460 / 91$ & (30) \\
\hline Aval & $726 / 453$ & (14) & 0 & (6) & 0 & (3) \\
\hline AvaII & 0 & (14) & $477 / 53$ & (4) & $498 / 53$ & (6) \\
\hline Dde I & $548 / 286 / 154 / 132 / 56$ & (16) & $233 / 227 / 56 / 1$ & $4(54)$ & $242 / 168 / 127 / 1$ & $4(38)$ \\
\hline Dra I & 0 & (14) & $290 / 240$ & $(16)$ & $299 / 252$ & (8) \\
\hline HaeIII & $873 / 303$ & (32) & 0 & $(16)$ & 0 & (7) \\
\hline Hind111 & 0 & (13) & 0 & $(9)$ & $505 / 46$ & (4) \\
\hline HinfI & $631 / 334 / 134 / 34 / 27 / 16$ & $(153)$ & $487 / 27 / 16$ & (204) & $456 / 52 / 27 / 16$ & $(101)$ \\
\hline M sp I & $875 / 301$ & (13) & 0 & (6) & 0 & (4) \\
\hline Ncil & $875 / 301$ & (13) & 0 & (6) & 0 & (4) \\
\hline Nde II & 0 & (13) & $389 / 141$ & (4) & $398 / 153$ & (6) \\
\hline PstI & $777 / 399$ & (13) & 0 & (4) & 0 & (2) \\
\hline PvuII & $814 / 362$ & (13) & 0 & (4) & 0 & (2) \\
\hline Rsal & $1002 / 114 / 60$ & (14) & $248 / 167 / 115$ & $(6)$ & $260 / 178 / 114$ & (3) \\
\hline ScrF I & $823 / 302 / 51$ & (13) & $479 / 51$ & (3) & $500 / 51$ & (2) \\
\hline StyI & 0 & (13) & $369 / 161$ & $(4)$ & $378 / 173$ & (2) \\
\hline TaqI & $526 / 385 / 201 / 64$ & (13) & 0 & (14) & $434 / 118$ & (12) \\
\hline
\end{tabular}


Table 3. GH-1 intron C percent DNA sequence di vergence. The anal ysi s used pairwise di vergences at 702 total nucl eotide sites al i gned anong the five sequences.

\begin{tabular}{|c|c|c|c|c|c|c|}
\hline \multicolumn{2}{|c|}{ Speci es/ A I el e } & $\begin{array}{l}\text { Coho } \\
\text { GH -I*a }\end{array}$ & $\begin{array}{l}\text { Coho } \\
\text { GH }-1 * b\end{array}$ & $\begin{array}{l}\text { Coho } \\
G H-1^{\star} C\end{array}$ & $\begin{array}{l}\text { Rai nbow } \\
\text { GH -1 }\end{array}$ & $\begin{array}{l}\text { Chi nook } \\
\text { GH-1 }\end{array}$ \\
\hline Coho & $\mathrm{GH}-\mathrm{I}^{* a}$ & - & & & & \\
\hline Coho & $\mathrm{GH}-\mathrm{I}^{*} \mathrm{~b}$ & 1.1 & - & & & \\
\hline Coho & $\mathrm{GH}-\mathrm{I}^{*} \mathrm{C}$ & 1.4 & 0.7 & & & \\
\hline Rai nbow & GH-1 & 3.0 & 2.3 & 2.3 & - & \\
\hline Chi nook & $\mathrm{GH}-1$ & 5.5 & 4.8 & 4.8 & 3.6 & $=$ \\
\hline
\end{tabular}

Tabl e 4. Segregati on of GH-1 i nt ron C PCR product I ength vari ants in captive broods of coho salmon. $\mathrm{GH}-1 * \mathrm{*}=\mathbf{1 1 7 8}$ bp; $\mathrm{GH}-1 * \mathrm{~b}=1111$ bp.

\begin{tabular}{|c|c|c|c|c|c|}
\hline \multirow[t]{2}{*}{ Fami l y } & \multirow{2}{*}{$\begin{array}{r}\text { Parental } \\
\text { Female }\end{array}$} & \multirow{2}{*}{$\begin{array}{c}\text { Genot ypes } \\
\text { Male }\end{array}$} & \multicolumn{2}{|c|}{ of $\mathrm{f} \mathrm{spring}$} & \multirow{2}{*}{$\begin{array}{c}\text { Counts } \\
\text { bb }\end{array}$} \\
\hline & & & $a a$ & $a b$ & \\
\hline $\mathrm{u} 2$ & $a b$ & $\mathrm{bb}$ & 0 & 10 & 10 \\
\hline u3 & $\mathrm{ad}$ & bb & 0 & 20 & 0 \\
\hline $\mathrm{u} 7$ & da & ab & 8 & 12 & 0 \\
\hline
\end{tabular}


Tabl e 5. Genotype and al I el e frequenci es at the GH-1 I ocus i $n$ hatchery and wi I d collections of coho sal mon. To test for expected bi nomal genotype proportions the I ess common allel es $\left(* b\right.$ and $*^{*}$ ) were pool ed. ns $=$ not si gni fi cant.

\begin{tabular}{|c|c|c|c|c|c|c|c|c|c|c|c|}
\hline \multirow[b]{2}{*}{ Col l ect i on } & \multirow[b]{2}{*}{$\mathrm{N}$} & \multicolumn{6}{|c|}{ GH-1 Genot ype Counts } & \multicolumn{3}{|c|}{ Al I el e Freq. } & \multirow[b]{2}{*}{$x^{2}$} \\
\hline & & aa & $a b$ & $\mathrm{bb}$ & & bc & $\mathrm{CC}$ & a & $b$ & $\mathrm{C}$ & \\
\hline Sandy Hat chery & 33 & 26 & 4 & 0 & 3 & 0 & 0 & 0.894 & 0.061 & 0.045 & $0.49^{\mathrm{ns}}$ \\
\hline Cl ackamas Wild 1 & 34 & 18 & 9 & 0 & 6 & 0 & 1 & 0.750 & 0.132 & 0.118 & $1.05^{\mathrm{ns}}$ \\
\hline Cl ackamas Wild 2 & 20 & 13 & 3 & 0 & 3 & 0 & 0 & 0.842 & 0.079 & 0.079 & $0.90^{\mathrm{ns}}$ \\
\hline Rock $\mathrm{Cr}$. Hat chery & 30 & 15 & 7 & 0 & 7 & 1 & 0 & 0.733 & 0.133 & 0.133 & $1.12^{\mathrm{ns}}$ \\
\hline Fal I Cr. Hat chery & 25 & 6 & 11 & 6 & 1 & 1 & 0 & 0.480 & 0.480 & 0.040 & $0.04^{\mathrm{ns}}$ \\
\hline Nehal em W $\mathbf{W}$ d 1 & 28 & 8 & 12 & 4 & 1 & 3 & 0 & 0.518 & 0.411 & 0.071 & $0.38^{\mathrm{ns}}$ \\
\hline vehal em Wild 2 & 33 & 15 & 10 & 5 & 3 & 0 & 0 & 0.652 & 0.303 & 0.045 & $0.58^{\mathrm{ns}}$ \\
\hline
\end{tabular}

Table 6. Tests for GH-1 al I el e frequency differences bet ween collections. Data are from Table 4 . All tests are $2 \times 3$ chi-square contingency tests ( $d f=2)$. Si gnifi cances are determined by Monte Carlo si mul ation.

$* \varangle \mathrm{P} 0.05, \quad * * \mathrm{P} \varangle 0.01, \quad * * * \mathrm{P} \varangle 0.001$.

\begin{tabular}{|c|c|c|c|c|c|c|}
\hline & Cl ackants & $\begin{array}{c}\text { Cl ackamas } \\
2\end{array}$ & Rock Cr. & Fal I $\mathrm{Cr}$. & $\begin{array}{c}\text { Nehal em } \\
1\end{array}$ & $\begin{array}{c}\text { Nehal em } \\
2\end{array}$ \\
\hline Sandy Hat chery & 4.75 & 0.52 & 5.52 & $27.56^{* * * *}$ & $23.08 * * *$ & $13.18^{* * *}$ \\
\hline Cl ackanas Wild 1 & - & 1.52 & 0.07 & $17.81^{* * *}$ & $12.46 * *$ & 7.10 \\
\hline Cl ackamas Wild 2 & & & 1.90 & $17.36^{* * *}$ & $13.64 * * *$ & $7.70^{*}$ \\
\hline Rock Cr. Hat chery & & & & 16. $71 * * *$ & $11.55^{* *}$ & 7. $16^{*}$ \\
\hline Fal I Cr. Hat chery & & & & & 0.82 & 3.82 \\
\hline Nehal em W'I d 1 & & & & & & 2.23 \\
\hline
\end{tabular}


Table 7. Associ ati on of genotypes of coho sal mon at $\mathbf{G +} \mathbf{2}$ with gender. The $* \mathbf{a}$ and $* \mathbf{b}$ al l el es were scored by the size of HinfIrestricti on fragnents (Fi g. 2).

\begin{tabular}{|c|c|c|c|c|c|}
\hline Col I ecti on & $\begin{array}{c}\text { Fenal es } \\
\text { a a } \\
-\end{array}$ & $\begin{array}{c}\text { Mal es } \\
\text { ab } \\
-1\end{array}$ & $\begin{array}{l}\text { Unk } \\
\text { ad } \\
\cdots\end{array}$ & ab & $\begin{array}{c}\text { Freq. } \\
G H-2^{\star} a b\end{array}$ \\
\hline Sandy Hatchery & 14 & 19 & $-\cdot$ & -- & 0.58 \\
\hline Rock Cr. Hatchery & 13 & 17 & $\cdots$ & $-\cdot$ & 0.57 \\
\hline Fal I Cr. Hatchery & 20 & $5^{\star}$ & -- & -- & --- \\
\hline Nehal em $V^{*}$ I d & $\cdots$ & $\because$ & 32 & 29 & 0.52 \\
\hline Cl ackanas $\quad V^{*} / \mathrm{d}$ & $\because$ & 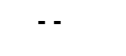 & 28 & 27 & 0.51 \\
\hline Total & 47 & 41 & 60 & 56 & 0.52 \\
\hline
\end{tabular}

*Fal I Creek $f i$ sh were sel ected on the basi s of gender for experi mental matings; ther ef ore, the frequency of $G H-2 \star b$ is not a random sample of thi s popul ation.

Table 8. Inheritance of variability at $\mathbf{G +} \mathbf{2}$ in experi nental capti ve broods (24) of coho sal mon. The *a and $* b$ al lel es were scored by the si ze of HinFI restriction fragnents ( Fi g. 2).

\begin{tabular}{|c|c|c|c|c|}
\hline \multirow[b]{2}{*}{ Fami I y } & \multicolumn{2}{|c|}{ Parents } & \multicolumn{2}{|c|}{ Of f spri ing } \\
\hline & Fenal e & Male & $\mathrm{ad}$ & $a b$ \\
\hline $\mathrm{u} 2$ & ad & ab & 13 & 7 \\
\hline u3 & $a a$ & ab & 10 & 10 \\
\hline u7 & $a a$ & $\mathbf{a b}$ & 8 & 12 \\
\hline
\end{tabular}


Table 9. G+ 2 i ntron $C$ percent sequence di vergence. The anal ysi s used pairwise di vergences at 432 total nucl eotide si tes al i gned anong the four sal non sequences (above di agonal), and 419 si tes al i gned anong al I si $x$ sequences ( bel ow di agonal).

\begin{tabular}{|c|c|c|c|c|c|c|c|}
\hline & & $\begin{array}{l}\text { Chi nook } \\
G H-2^{\star} a\end{array}$ & $\begin{array}{l}\text { Chi nook } \\
G H-2^{\star} b\end{array}$ & $\begin{array}{l}\text { Coho } \\
G H-2^{\star} a\end{array}$ & $\begin{array}{l}\text { Coho } \\
G H-2 \star b\end{array}$ & $\begin{array}{l}\text { Rai nbow } \\
\text { G+ } 2\end{array}$ & $\begin{array}{l}\text { Cut thr oat } \\
\text { G+ } 2\end{array}$ \\
\hline Chi nook & $G H-2^{\star} a$ & - & 7.4 & 0.9 & 6.0 & - & - \\
\hline Chi nook & $G H-2 * b$ & 7.2 & - & 7. 9 & 3. 9 & - & - \\
\hline Coho & $G H-2^{\star} a$ & 1.0 & 7.6 & - & 6.5 & - & - \\
\hline Coho & $G H-2^{\star} b$ & $5 \cdot 7$ & 4.5 & 6.2 & - & & \\
\hline Rai nbow & G+ 2 & 2. 1 & 6.9 & 2.6 & 5.0 & - & - \\
\hline Cutt hroat & GH 2 & 3.6 & 7.9 & 4.1 & 6.4 & 1.9 & - \\
\hline
\end{tabular}


Tabl e 10. RAPD pol ynorphi sns i n hatchery coho sal non and hatchery rai nbow trout.

\begin{tabular}{lll} 
Nb. Fi sh Tested & 10 & 19 \\
Nb. Pri mers & 15 & 15 \\
Nb. Scorable Bands & 51 & 49 \\
Nb. Vari abl e Bands & 14 & 24 \\
\hline
\end{tabular}

Tabl e 11. Marker frequenci es for RAPD pri mers $A 2$ and $A 10$ in two hat chery collections of coho sal non.

\begin{tabular}{|c|c|c|c|}
\hline Marker & Sandy & Rock Cr. & Prob. \\
\hline$A 2 / 1$ & 0.83 & 0.87 & 1.00 \\
\hline$A 10 / 1$ & 0.97 & 0.85 & 0.17 \\
\hline $\mathrm{A} 10 / 2$ & 0.14 & 0.00 & 0.12 \\
\hline$A 10 / 3$ & $\bar{u} . \bar{y} \bar{i}$ & $\bar{u} . \overline{8} \bar{y}$ & 1.00 \\
\hline A10/4 & 0.25 & 0.44 & 0.17 \\
\hline$A 10 / 5$ & 0.00 & 0.13 & 0.09 \\
\hline
\end{tabular}

Combi ned Prob.

co. 10 
Fi gure 1. Pol ynorphi sm of GH-1 i ntron C PCR products i n coho sal mon. Lanes 1-19: three al I el es (1178 bp, 1111 bp, 1083 bp) segregate at GH-1 i n 19 unrel at ed i ndi vi dual s. Lane 20: 1Kb DNA Ladder (G bco- BRL).

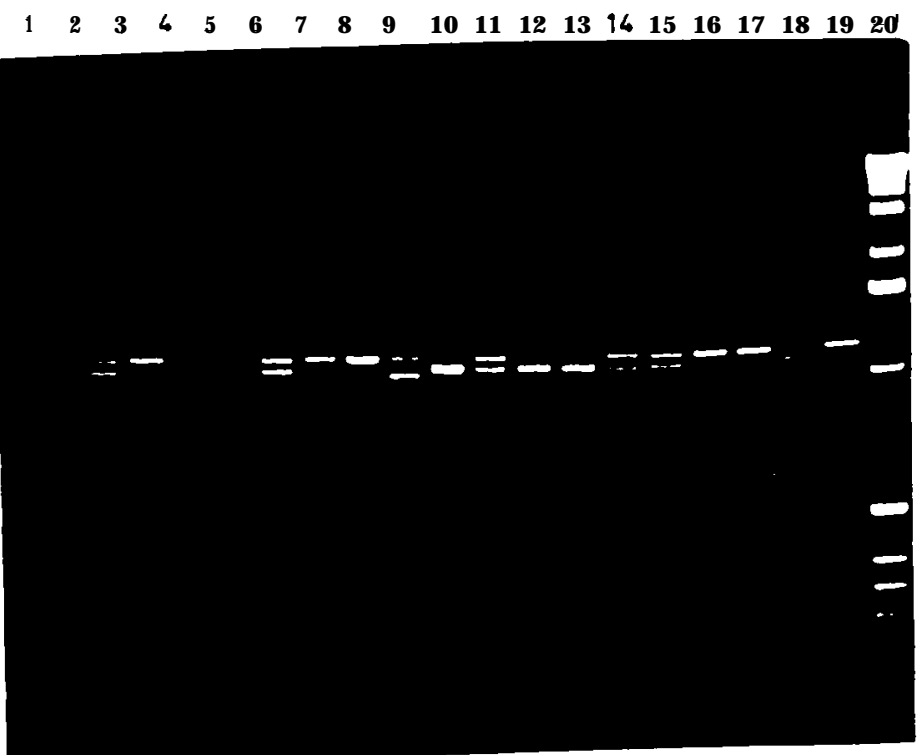


Fi gure 2. Segregati on of $\mathbf{G H} 2$ al I el es i n coho sal mon experi mental brood U2. Lanes 1 and 18: IKb DNA Ladder ( $\mathbf{G}$ bco-BRL). Hinfl di gests of $\mathbf{G +} 2$ i ntron $\mathbf{C}$ PCR products are shown for the fenale and male parents ( $I$ anes 2 and 3) and 14 of f spring ( $I$ anes 4-17), in a 2.5\% agar ose gel. The 488- bp fragment (I ane 2) represents the GH-2*a product ( 530 bp total). The 456-bp fragnent (I ane 3) is characteristic of the Y-Ii nked $G H-2 \star b$ product ( 551 bp total). The bri ght ness of $G H-2^{\star}$ a i $\mathbf{n}$ mal es vari ed markedl y anong unrel ated i ndi vi dual s, but the $Y$ I i nked $G H-2 \star b$ band was al ways bright when present. Thi s variati on is I i kel y due to PCR pri mer si te di fferences anong $G H-2 \star a-t y p e$ al I el es.

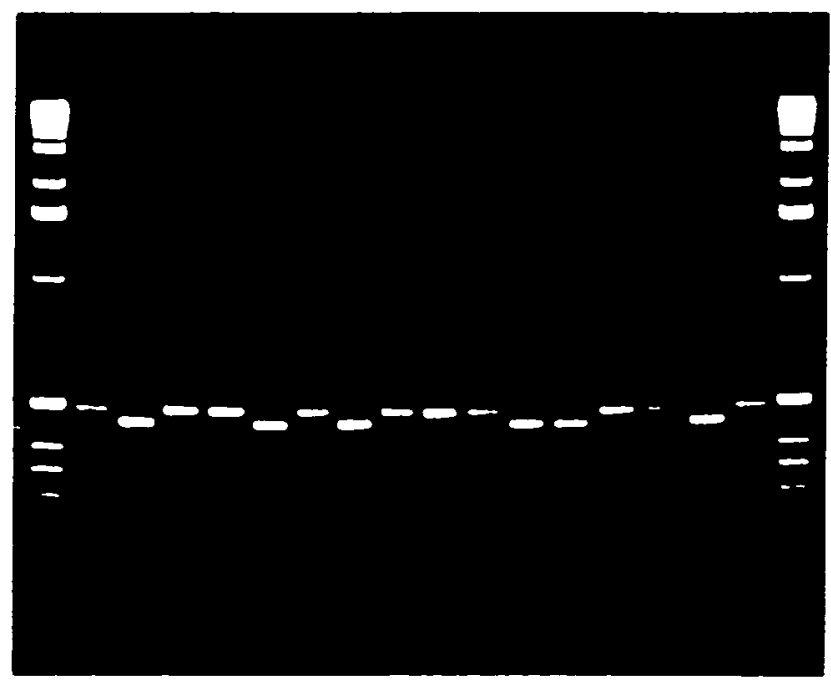


Fi gure 3. DNA sequences of coho sal mon GH-1 i ntron C PCR products. Nucl eoti des whi ch are al i gnable wi th coho $\mathbf{G + 2}$ are marked (*). Three al lel es $\left(G H-1{ }^{\star} a,{ }^{\star} b,{ }^{\star} c\right)$ have 11,9 and 8 cont i guous copi es of the 31 -bp tandem repeat, respecti vel $y$. The ent i re GH-1 sequence is al $i$ gnabl e wi th rai nbow trout and chi nook sal mon GH-1 except for the coho tandem repeats, whi ch are absent in these other speci es.

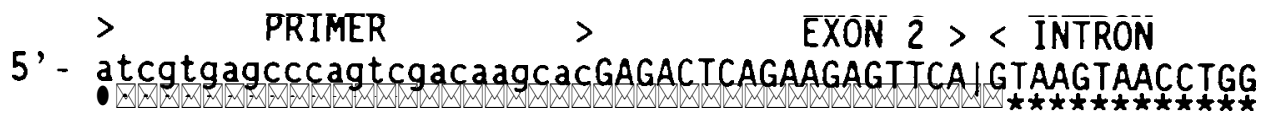

CTGAGACAATTACTCATGTTATGCCCTTTAGAACCATATATCGTGACAGTTCCACTC

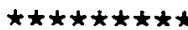

TGCTATTCACCTTAAATATGAACTCCTCCATGATGCAAGATISGAAAATAATAATAGGGCATCTC

AATTTGAACAATCGATAGAACTTAGTCATTAGTCATTGGGCAAGCAGACCACCACTTATGTAAACTC

\section{AAATTTATATTCATCTTTATTTATTTATTATATTITATITT}

Tandem Repeats

$$
\begin{aligned}
& \text { a: [agccTTTAATTTATTITITATGTTTTATTTT] } \mathbf{X} \mathbf{1 1} \\
& \text { b: [agcCTTTAATTTATTTTTTATGTTTTATTTT] } \mathbf{X} \mathbf{9} \\
& \text { c: [agccTTTAATTTATTTTTTATGTTTTATTTT] X } 8
\end{aligned}
$$

agcCTTTAATTAACTTGGCAAGTCAGTTAAGAACAAATTCTCATTTACAATGACAAGCAGATGG

$$
\begin{aligned}
& \text { ATCATGCATGGCTCTCGAGTGGCACATCAGTCTAAGGCACTACATCTCAGTGCCAGAGGTGTCACTG }
\end{aligned}
$$

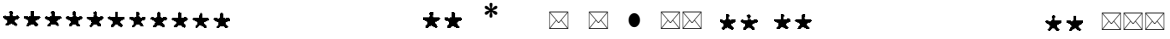

$$
\begin{aligned}
& \text { CAGACCCTGGTCGATTCCAGACTGTATTTCAAACAGCTGTGATTGTGAGTCCCATAGGGCGGCACAC } \\
& \text { AATTCTCCCAGCGTCGTTAGGGTTTGGCCGGGGTTGCAATACCTCAGTGTCTTCAAATAAGGTAGAT } \\
& \text { AAAACAACCACATATCAGTGCAAGTAAAACC - ATCACTGTCTAATCGGTGGATTCTCTATGTCTACA } \\
& \text { TTCTCTGTTTTGTGCTITTCTGTACAGGAAACCCGCCCCAAAAGTATTTCACTCAATCATGTAAATA } \\
& \text { GGGCATCTCAAGCTGTACAATACAACTCAACTTCATTTTCCAATAATCTGTGGTTTCTCTACATCTT } \\
& \text { I NIRON > < EXON } 3 \text { < PR MER < } \\
& \text { CACACACAG | GTCCTGAAGCTGCTCCATATTTCTTINNNcçtgat tgaatcctgggagtaccC }
\end{aligned}
$$


Fi gure 4. Segregation of GH-1 al l el es *a and *b i $n$ an experi mental brood of coho sal mon. Lanes 1 and 18: IKb DNA Ladder ( $G$ bco- BRL). Lanes 2-4: unrel ated adults. Lanes 5 and 6: fenal e and mal e parents. Lanes 7-17: of f spring.

$\begin{array}{llllllllllllllllll}1 & 2 & 3 & 4 & 5 & 6 & 7 & 8 & 9 & 10 & 11 & 12 & 13 & 16 & 15 & 16 & 17 & 18\end{array}$

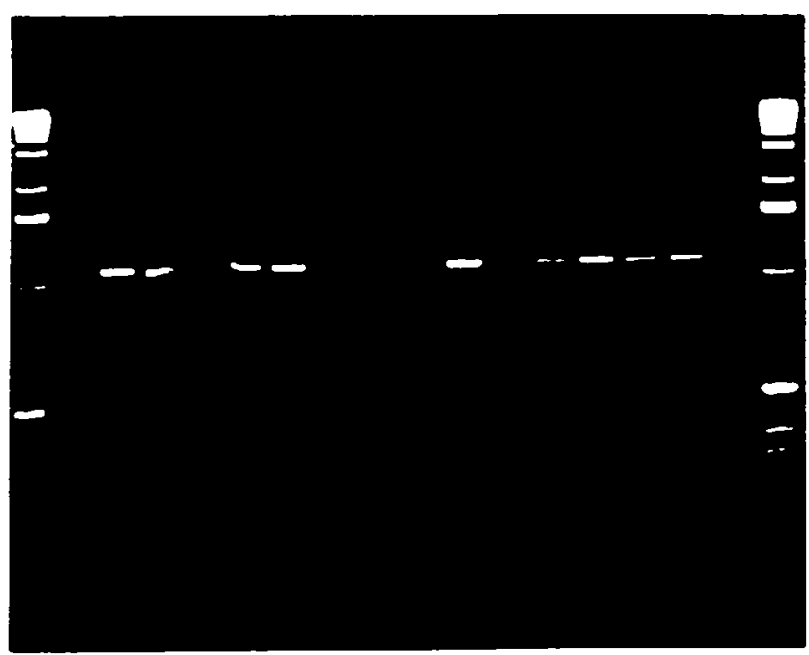


Fi gure 5. Dendrogram of genet i c di stances based on GH-1 al l el e Frequenci es in coho sal non collections. Data are from Table 5. Onl y differences bet ween the Lower Col unbi a and Oregon Coast cl usters are stati stical ly si gnifi cant

( Table 6).

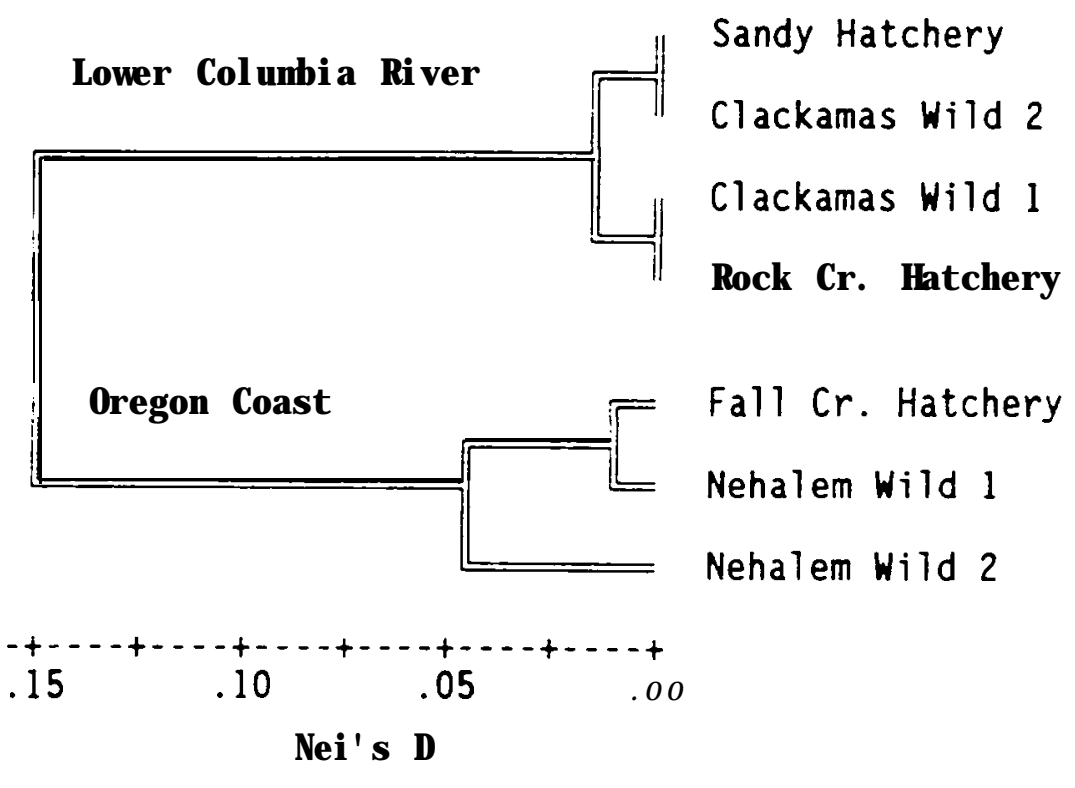


Fi gure 6. DNA sequence of coho sal mon $\mathrm{GH} 2$ intron C PCR products. H if I restriction si tes are underli ned, i ncl udi ng the one di sti ngui shing the *b al l el e from the *a al l el e (79 bp). Nucl eoti de mismatches and al $i$ gnment gaps are marked $(*)$.

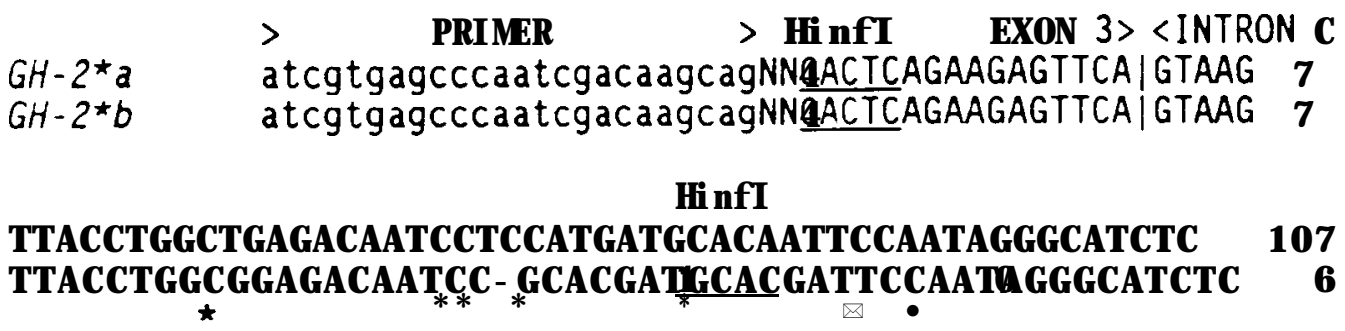

AATTTGAACAA ............... GTCATTAGTTATTGGGCAAGCAGATCCCCGATTGTC 154 AATTTGAATAATCGATACAACTTAGTCATTAGTTATTGGGCAAGCAGATCCCCAATTGTC 166

TAAACTCCATGGTTAATATATACTGTAGATAAGCAGAACCAGCATCATGCATGGTG 214 TAAACTCCATGGGTAAATATATACTGTAGAAAAGCAGAACCAGCATCATGCATGGTGGAA 226

ATTAAATCTAGCCATGACAGGAAGTTTTAAATTGTACACTTAAAATCAACAGTAAAATGT 274 ATTAAATCTAGCCATGATAGGGAGTTTTAAATTGTACACTTAAAATCGGCAGTAAAATGT 286

TGCTATACCTCAGTGCCTTCAACTAAGGTAGGTCAAACATCACATATCACAGTCCTTG 334 TGCTATACCTCAGTGCCTTCAATTAAGGTAGGTAAAACAACCACACACCATAGCCCTTG 345

TAAGTAAAACCCATCACTCTCTAATCGGCGGTTTCTCTACGTCTACATTCTCCAGCAATG 394 GAAGTAAAACTCATCACTCTCTAATCGGCGGGTTCTCTACGTCTACATTCTCCAGCCATG 405

TTT-ATGT - . . . . - GGCATCTCAAGCTGTACAATTACAACTCAACTTCATTTTCTAA 444 TATCATGTAAATGATATGTCATCTCAAGCTGTACAA-TACAATTCAACTTCATTTTCTAA 464

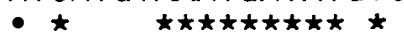

TCATCTGTGGTTTCTCTACATCTACACACACAG|GTCCTGAAGCTGCTCCATATCTCTTT 503 TAATCTGTGTTTTCTCTACATCTACACACACAG GTCCTGAAGCTTCTCCATATCNNNNN 523

I NIRON C > $<$ EXON 4

$<$ HInT̈l PRIMEK <

CNNcctgat tgaatcctgggagtaccC 530

NNNcctgattgaatcctgggagtaccC 551 
Fi gure 7. UPGMA (unuei ghted pai $r$ group usi ng arithmetic averages) cl uster anal ysi $s$ of sequence di vergence bet ween $\mathrm{G}+2$ intron $\mathrm{C}$ al I el es in coho sal mon and chi nook sal mon. The anal ysi s used pai $r$ - wi se di vergences at 432 total nucl eot i de si tes al i gned anong the four sequences (Tabl e 9).

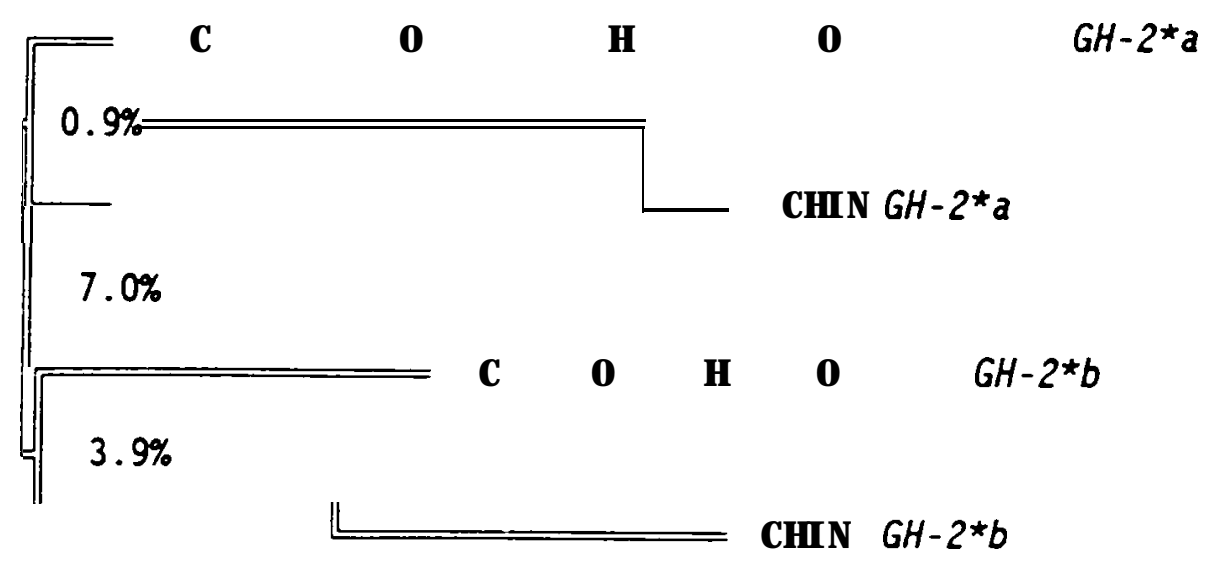

